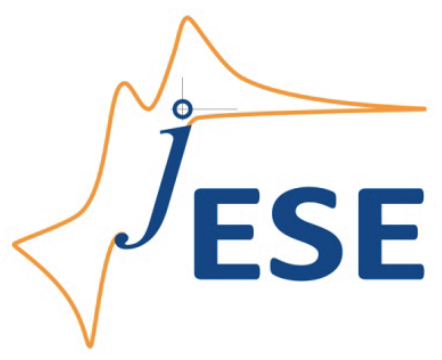

Open Access : : ISSN 1847-9286

www.jESE-online.org

Original scientific paper

\title{
Platinized titanium dioxide electrodes for methanol oxidation and photo-oxidation ${ }^{\S}$
}

\author{
SVETLOZAR IVANOV, IOANNA MINTSOULI*, JENIA GEORGIEVA, STEPHAN \\ ARMYANOV, EUGENIA VALOVA, GEORGIOS KOKKINIDIS*, IOANNIS POULIOS*, \\ SOTIRIS SOTIROPOULOS*
}

Rostislaw Kaischew Institute of Physical Chemistry, Bulgarian Academy of Sciences, Sofia 1113, Bulgaria

*Department of Chemistry, Aristotle University of Thessaloniki, Thessaloniki 54124, Greece

${ }^{\otimes}$ Corresponding Author: E-mail: eczss@chem.auth.gr; Tel.: +30-2310-997742; Fax: +30-2310-997709

Received: September 3, 2012; Published: November 10, 2012

${ }^{\S}$ Dedicated to $75^{\text {th }}$ birthday of Professor Sergio Trasatti

\begin{abstract}
Platinized deposits have been formed on $\mathrm{TiO}_{2}$ particulate films supported on $\mathrm{Ti}$ substrates, by means of galvanic replacement of pre-deposited metallic $\mathrm{Cu}$ and subsequent immersion of the $\mathrm{Cu} / \mathrm{TiO}_{2}$ coatings into a chloroplatinic acid solution. The spontaneous replacement of $\mathrm{Cu}$ by $\mathrm{Pt}$ results in $\mathrm{Pt}(\mathrm{Cu}) / \mathrm{TiO}_{2} / \mathrm{Ti}$ electrodes. Both the platinized and the precursor $\mathrm{TiO}_{2} / \mathrm{Ti}$ electrodes have been characterized by SEM microscopy/EDS spectroscopy, their surface electrochemistry has been assessed by cyclic voltammetry in the dark and their photoelectrochemical properties by photovoltammetry under UV illumination. It has been found that, although platinized rutile-rich electrodes exhibit typical Pt surface electrochemistry, the anatase-rich electrodes show only traces of oxide formation and stripping. The latter has been translated to a suppression of methanol oxidation at anatase-rich electrodes. On the contrary, methanol oxidation at platinized rutile-rich electrodes occurs at significant rates and can be further enhanced upon UV illumination, as a result of Pt and $\mathrm{TiO}_{2}$ synergism in the photoelectrochemical oxidation of methanol.
\end{abstract}

Keywords

Titanium dioxide; platinum; galvanic replacement; electrocatalysis; photoelectrocatalysis 


\section{Introduction}

Platinized $\mathrm{Ti}$ or $\mathrm{TiO}_{2}$ finds a number of practical applications that include industrial anodes, photocatalysis/photoelectrocatalysis and fuel cell catalysts. In more detail, $\mathrm{Ti}$ (with native, thermally or electrochemically grown $\mathrm{TiO}_{2}$ on it) is the basis of dimensionally stable anodes (DSAs) which are coated with precious metal and other oxide catalysts and are used in many industrial processes (e.g. chlorine production, water electrolysis, electrowinning etc) [1-4]. Also, modifying the semiconductor oxides of $\mathrm{TiO}_{2}$ by precious metals (especially $\mathrm{Pt}$ ) is a well-established practice to improve their photocatalytic efficiency by reducing photogenerated electron-hole recombination rates [5-7]. Finally, $\mathrm{Pt} / \mathrm{TiO}_{2}$ bi-component powder catalysts mixed with high surface area carbons have recently been tested as alternative anode or cathode catalysts in fuel cells [8-10].

Methods for $\mathrm{Pt}$ deposition/incorporation onto/into $\mathrm{TiO}_{2}$ supported layers include electrodeposition [11-14], vacuum deposition [15], thermal decomposition followed by reduction [16] and photodeposition [17,18]. Platinization of $\mathrm{TiO}_{2}$ powders is almost exclusively carried out by chemical reduction of $\mathrm{Pt}$ complexes in the presence of $\mathrm{TiO}_{2}$ particles or simultaneously with $\mathrm{TiO}_{2}$ sol-gel preparation [19]. Electrodeposition allows for accurate control of precious metal loading but requires specialized equipment, uses concentrated precious metal solutions and it is difficult to apply to powder substrates; chemical methods usually involve reducing agents and almost always involve a high temperature annealing in a reducing atmosphere; photodeposition is a lengthy process and can also lead to precious metal losses due to uncontrolled deposition at reactor components other than the substrate [17].

During the last decade an alternative method for the introduction of the noble metal onto the electrode support has been developed. The method is based on the spontaneous galvanic replacement of surface layers of a non-noble metal $\mathrm{M}(\mathrm{M}: \mathrm{Pb}, \mathrm{Cu}, \mathrm{Fe}, \mathrm{Co}, \mathrm{Ni}$ ) by a noble metal (e.g. $\mathrm{Pt}, \mathrm{Au}, \mathrm{Pd}, \mathrm{Ir}$ ) upon immersion of the former in a solution of metal ions of the latter (the resulting bimetallic system is denoted as $\mathrm{Pt}(\mathrm{M}), \mathrm{Au}(\mathrm{M})$ etc.). For example, in the case of $\mathrm{Cu}$ and $\mathrm{Pt}$ :

$$
2 \mathrm{Cu}+\mathrm{PtCl}_{6}{ }^{2-} \rightarrow \mathrm{Pt}+6 \mathrm{Cl}^{-}+2 \mathrm{Cu}^{2+}
$$

The method (also known as transmetallation) was first applied by Adžić and co-workers to underpotentially deposited (UPD) $\mathrm{Cu}$ monolayers [20-22] and to $\mathrm{Cu}$ and $\mathrm{Pb}$ bulk deposits by Kokkinidis and co-workers [23-24] on flat electrode substrates. It has since been extended to other transition metals (Fe, Co, Ni) (see for example the works of Sotiropoulos and co-workers [25-30]) as well as to carbon powder supports (see for example [31,32]). Advantages of the new technique include the fact that it is a fast and room temperature processes, it employs low concentration solutions of the precious metal and can lead to the formation of thin precious metal deposits that may decrease its loading.

Despite the rapid evolution of the application of the technique on conducting substrates, the formation of metal/semiconductor (e.g. $\mathrm{Pt} / \mathrm{TiO}_{2}$ ) catalysts by means of transmetallation has yet to be established. These systems should offer the possibility of enhancing anodic reactions occurring at Pt by means of simultaneous photooxidations at $\mathrm{n}$-type semiconducting supports and to that direction, methanol oxidation at UV-illuminated $\mathrm{Pt} / \mathrm{TiO}_{2}$ electrodes has recently been reported [33].

The aim of this work has been to investigate the feasibility of applying the galvanic replacement technique to the metallization of $\mathrm{TiO}_{2}$ powders. Specific objectives have been:

i. The preparation and microscopic as well as compositional characterization of $\mathrm{Pt}(\mathrm{Cu}) / \mathrm{TiO}_{2}$ deposits on Ti substrates ; 
ii. The electrochemical characterization of the deposits by means of Pt surface electrochemistry and methanol oxidation;

iii. The study of the effect of UV illumination on the electrochemical behavior of these deposits.

\section{Experimental}

\section{Preparation of $\mathrm{TiO}_{2} / \mathrm{Ti}, \mathrm{Cu} / \mathrm{TiO}_{2} / \mathrm{Ti}$ and $\mathrm{Pt}(\mathrm{Cu}) / \mathrm{TiO}_{2} / \mathrm{Ti}$ electrodes}

Ti rectangular substrates ( $0.5 \mathrm{~mm}$ thick) had typical dimensions of $1 \mathrm{~cm} \times 0.5 \mathrm{~cm}$ and were etched in a $\mathrm{HF} / \mathrm{HNO}_{3}$ 3:1 mixture and then washed with doubly distilled water. Known volumes of a $1 \mathrm{~g} \mathrm{~L}^{-1}$ methanol dispersion of Degussa $\mathrm{P}-25 \mathrm{TiO}_{2}$ were pipetted onto one side of the Ti substrate and the coating was dried at $50^{\circ} \mathrm{C}$ for $10 \mathrm{~min}$. $\mathrm{TiO}_{2}$ loadings were in the $2-3 \mathrm{mg} \mathrm{cm}^{-2}$ range. These coated substrates were sintered in an air atmosphere at $700^{\circ} \mathrm{C}$ (for $5 \mathrm{~h}$ ) or $500^{\circ} \mathrm{C}$ (for $1.5 \mathrm{~h}$ ) using a Carbolite CWF 1100 oven, resulting in particulate $\mathrm{TiO}_{2}$ layers. The back side of the samples had been etched again before it was insulated with epoxy resin glue (RS).

Electrodeposition of $\mathrm{Cu}$ on the $\mathrm{TiO}_{2} / \mathrm{Ti}$ electrode was performed at constant potential (in the mixed control potential regime and more specifically at the half-wave potential of exploratory deposition voltammetry) from $0.1 \mathrm{M} \mathrm{HClO}_{4}+0.01 \mathrm{M} \mathrm{CuSO}_{4}$ deaerated solutions. The total charge density passed was $400 \mathrm{mC} \mathrm{cm}$ for rutile-rich electrodes and 400 or $1200 \mathrm{mC} \mathrm{cm}^{-2}$ for anataserich electrodes.

The $\mathrm{Cu} / \mathrm{TiO}_{2} / \mathrm{Ti}$ electrodes were immersed in $2 \mathrm{ml}$ of a $0.1 \mathrm{M} \mathrm{HCl}+10^{-3} \mathrm{M} \mathrm{K}_{2} \mathrm{PtCl}_{6}$ solution for 30 min so that replacement of $\mathrm{Cu}$ by Pt could take place:

$$
2 \mathrm{Cu} / \mathrm{TiO}_{2} / \mathrm{Ti}+\mathrm{PtCl}_{6}{ }^{2-} \rightarrow \mathrm{Pt}(\mathrm{Cu}) / \mathrm{TiO}_{2} / \mathrm{Ti}+2 \mathrm{Cu}^{2+}+6 \mathrm{Cl}^{-}
$$

\section{Microscopic and spectroscopic characterisation of coatings}

Scanning Electron Microscopy (SEM) was carried out using a JEOL JSM-5510 microscope and elemental analysis of the coatings was performed by the accompanying EDS (EDAX) system. X-Ray Diffraction (XRD) deposit characterisation was performed with the help of a Rigakou Miniflex diffractometer.

\section{Electrochemical and photoelectrochemical characterisation of coatings}

Cyclic voltammetric and constant potential experiments on $\mathrm{TiO}_{2}$ electrodes in the dark and under UV illumination were carried out with the Autolab 30 (EcoChimie) system in a threeelectrode cell equipped with a flat quartz window opposite the working electrode. A saturated calomel electrode (SCE) was used as the reference electrode and a Pt foil as the counter electrode. Voltammograms were run for at least three consecutive full cycles since preliminary experiments showed that a near-steady state response was observed only after the second run; all results reported correspond to the stabilized voltammetric picture.

A Radium Ralutec 9W/78 UVA lamp $\left(\lambda=350-400 \mathrm{~nm}, \lambda_{\max }=366 \mathrm{~nm}\right)$, placed at a distance of $2.5 \mathrm{~cm}$ from the sample, was used for front face electrode illumination. The power density on the sample surface position was measured as $3 \mathrm{~mW} \mathrm{~cm}^{-2}$ with a photometer.

\section{Electrode materials and chemicals}

Ti plates $0.5 \mathrm{~mm}$ thick were from Alfa Aesar ( $99.5 \%$, metals basis). $\mathrm{TiO}_{2}$ powder was P-25 Degussa ${ }^{\circledR}$ from Degussa (now Evonic). $\mathrm{HClO}_{4}$ from Riedel, (puriss p.a., ACS reagent, $\geq 70 \%$ ) and $\mathrm{CuSO}_{4} \cdot 6 \mathrm{H}_{2} \mathrm{O}$ from Sigma-Aldrich (ACS reagent) were used in the preparation of $\mathrm{Cu}$ deposition solutions. $\mathrm{H}_{2} \mathrm{PtCl}_{6}$ hexahydrate from Sigma-Aldrich (ACS reagent, $\geq 37.50 \%$ as $\mathrm{Pt}$ ) was employed for 
the Pt exchange solution. $\mathrm{MeOH}$ was from Riedel (Chromasolv $^{\circledR}$, for HPLC, gradient grade, $\geq 99.9$ $\%)$.

\section{Results and Discussion}

$\mathrm{TiO}_{2}$ particulate films on Ti electrode substrates: microscopic, electrochemical and photoelectrochemical characterization

Figure 1 shows the SEM micrograph of the surface of a typical $\mathrm{Ti} / \mathrm{TiO}_{2}\left(700{ }^{\circ} \mathrm{C}\right)$ electrode. This is characterized by a reticulated network of micrometer-sized aggregates into which the much smaller anatase and rutile particles ( 22 and $31 \mathrm{~nm}$, as determined by XRD) of the original P-25 $\mathrm{TiO}_{2}$ material have been merged after annealing. The picture of $\mathrm{Ti}^{-} / \mathrm{TiO}_{2}\left(500{ }^{\circ} \mathrm{C}\right)$ electrodes was very similar, indicating that sintering at $500^{\circ}$ (for $1.5 \mathrm{~h}$ ) or $700{ }^{\circ} \mathrm{C}$ (for $5 \mathrm{~h}$ ) has the same effect on the overall morphology of the particulate films. However, as confirmed by XRD [34], the $500{ }^{\circ} \mathrm{C}$ treated samples retain the $75 \div 25 \% \mathrm{w} / \mathrm{w}$ anatase-to-rutile composition (and are termed anataserich or $\mathrm{TiO}_{2}-500$ samples hereafter) while the $700^{\circ} \mathrm{C}$-treated samples are transformed to rutile-rich samples $\left(3 \div 97 \% \mathrm{w} / \mathrm{w}\right.$ anatase-to-rutile; $\left.\mathrm{TiO}_{2}-700\right)$.

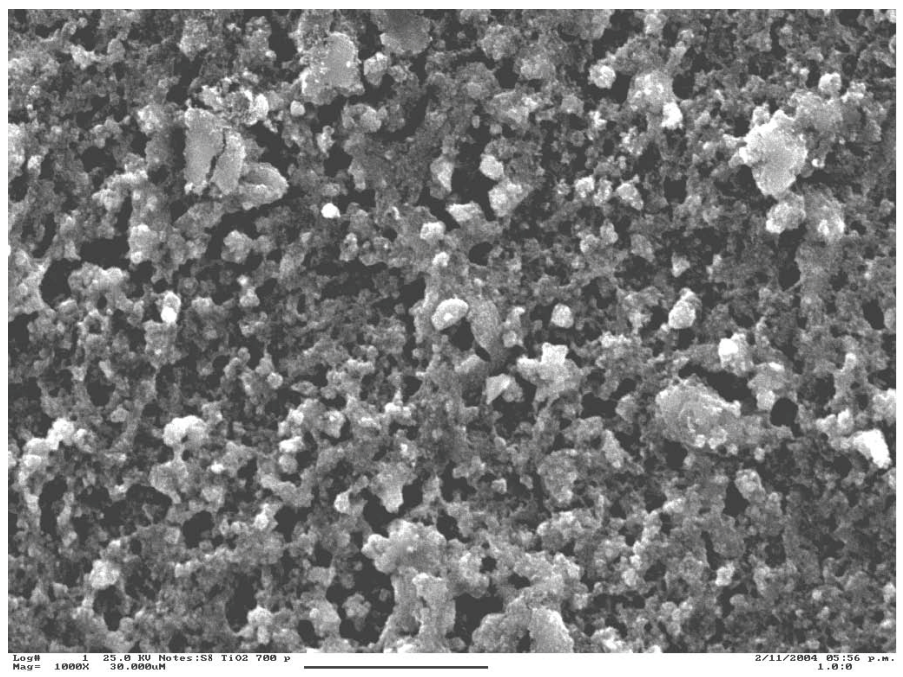

Figure 1. SEM micrograph of a $\mathrm{TiO}_{2}$ particulate film prepared on a Ti substrate by annealing solution-cast Degussa $\mathrm{P}-25^{\circledR} \mathrm{TiO}_{2}$ particles at $700^{\circ} \mathrm{C}$ for $5 \mathrm{~h}$. (Scale bar length: $30 \mu \mathrm{m}$.)

\section{Electrochemical characterisation of $\mathrm{TiO}_{2}$ coatings in the dark}

Figure 2 presents fast $\left(100 \mathrm{mV} \mathrm{s}^{-1}\right)$ cyclic voltammograms in the dark of an anatase-rich $/ 500{ }^{\circ} \mathrm{C}$ electrode (with a $4.3 \mathrm{mg} \mathrm{cm}^{-2} \mathrm{TiO}_{2}$ loading) and a rutile-rich/700 ${ }^{\circ} \mathrm{C}$ electrode (with a $2.4 \mathrm{mg} \mathrm{cm}^{-2}$ $\mathrm{TiO}_{2}$ loading), in a $1 \mathrm{M} \mathrm{HClO}_{4}$ solution. Prior to hydrogen evolution, a couple of cathodic and anodic main peaks are observed (together with traces of another couple at more positive potentials), attributed to the surface transformation of the $\mathrm{Ti}(\mathrm{IV}) / \mathrm{Ti}(\mathrm{III})$ couple at potentials negative to the flat band potential of $\mathrm{TiO}_{2}$ and just prior to hydrogen evolution [17,35-37].

The charge density (per geometric substrate area) under the cathodic peaks was found to be $7.5 \mathrm{mC} \mathrm{cm}{ }^{-2}$ for the anatase-rich $/ 500^{\circ} \mathrm{C}$ electrode and $2.8 \mathrm{mC} \mathrm{cm}{ }^{-2}$ for the rutile-rich $/ 700^{\circ} \mathrm{C}$ one. Since the value of $\mathrm{Ti}$ surface density in a $\mathrm{TiO}_{2}$ crystal has been reported as approximately $9 \mathrm{Ti}^{4+}$ ions $/ \mathrm{nm}^{2}$ [38], the $\mathrm{Ti}(\mathrm{IV}) / \mathrm{Ti}(\mathrm{III})$ transformation translates to an expected charge density of $144 \mu \mathrm{C} \mathrm{cm}^{-2}$. Then the sintered electrodes presented in Figure 2 have roughness factors of 52 and 19 electroactive $\mathrm{TiO}_{2} \mathrm{~cm}^{2}$ per substrate $\mathrm{cm}^{2}$. If we further take into account the $\mathrm{TiO}_{2}$ loading of these particular electrodes $\left(4.3 \mathrm{mg} \mathrm{cm}^{-2}\right.$ and $2.4 \mathrm{mg} \mathrm{cm}^{-2}$ respectively) then their mass-specific $\mathrm{TiO}_{2}$ 
electroactive area can be calculated as $1.2 \mathrm{~m}^{2} \mathrm{~g}^{-1}$ and $0.8 \mathrm{~m}^{2} \mathrm{~g}^{-1}$ for the anatase-rich and rutile-rich electrodes, respectively. The similar values of electroactive areas are in line with the similarities observed in the morphology by SEM analysis.

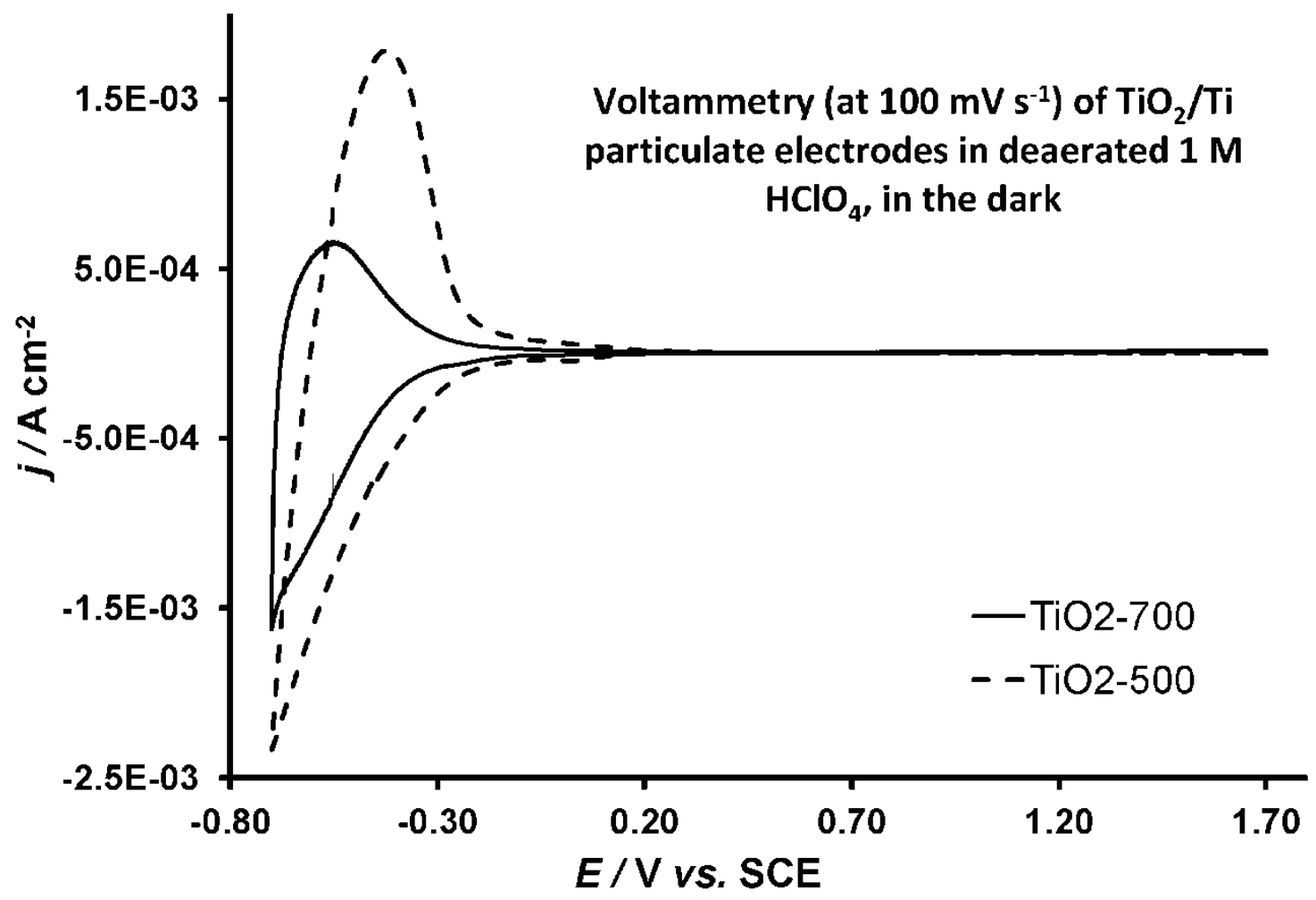

Figure 2. Cyclic voltammograms of $\mathrm{TiO}_{2} /$ Ti electrodes (anatase-rich/annealed at $500{ }^{\circ} \mathrm{C}$ for $1.5 \mathrm{~h}$ and rutile-rich/annealed at $700{ }^{\circ} \mathrm{C}$ for $5 \mathrm{~h}$ ) in $1 \mathrm{M} \mathrm{HClO}_{4}$, in the dark.

Figure 3(A) shows photovoltammograms (at $10 \mathrm{mV} \mathrm{s}^{-1}$ ) of two $\mathrm{TiO}_{2} / \mathrm{Ti}$ electrodes with similar loadings $\left(2.2-2.4 \mathrm{mg} \mathrm{cm}{ }^{-2}\right)$ at anatase- and rutile-rich $\mathrm{TiO}_{2}$ electrodes under UV illumination $(360 \mathrm{~nm}, 3 \mathrm{~mW} \mathrm{~cm})^{-2}$ ). If there are no other oxidizable species in solution, the observed photocurrent is due to water oxidation by photogenerated holes to $\mathrm{OH}^{\bullet}$ or other primary oxidation products such as $\mathrm{O}_{2}{ }^{-}$and $\mathrm{H}_{2} \mathrm{O}_{2}$. The limiting photocurrent observed at high positive potentials is controlled by the diffusion of photogenerated electrons through the particles of the particulate semiconductor layer [39-41]. The onset potential of the photocurrent (which can be approximated to the flat band potential) for the anatase-rich electrode is ca. $-0.150 \mathrm{~V}$ vs. SCE, lower by some 200 $\mathrm{mV}$ from that of the rutile-rich electrode, in line with anatase reported to have a more negative flatband potential than that of rutile [42]. Also, the limiting photocurrent in the plain electrolyte solution is found to be higher at the rutile-rich electrode, indicating its higher photoelectrocatalytic activity for water oxidation. Figure $3(\mathrm{~B})$ shows the effect of the addition of $0.5 \mathrm{M} \mathrm{MeOH}$ to the photovoltammetry. It is seen that, although the shift of the flatband potential remains the same, the limiting photocurrent of the anatase-rich electrode is now higher, most likely due a higher adsorption affinity for methanol on the anatase surface where it is oxidized by the photogenerated holes. 

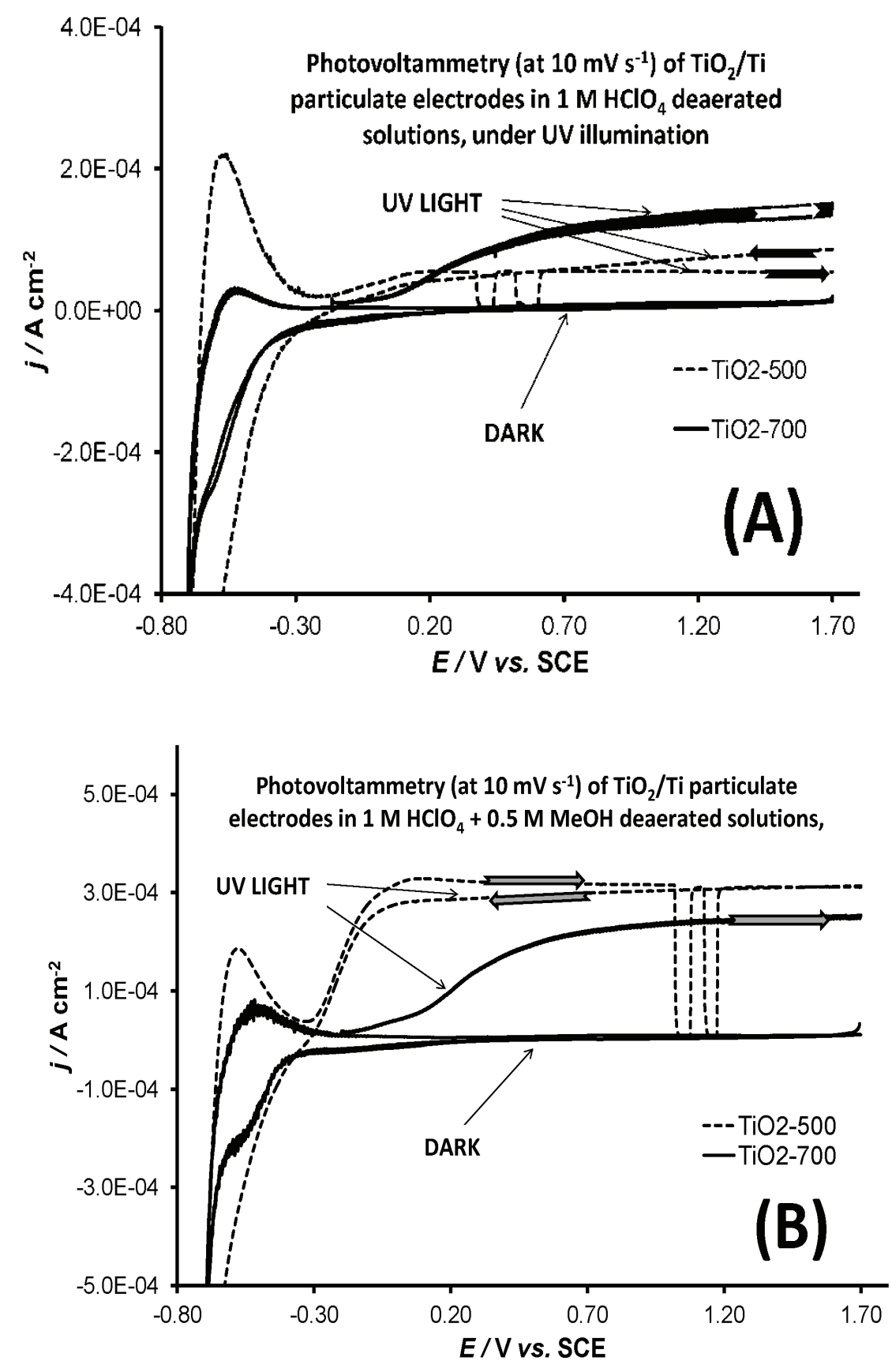

Figure 3. Cyclic voltammograms of $\mathrm{TiO}_{2} / \mathrm{Ti}$ electrodes (anatase-rich/annealed at $500{ }^{\circ} \mathrm{C}$ for 1.5 $h$ and rutile-rich/ annealed at $700^{\circ} \mathrm{C}$ for $5 \mathrm{~h}$ ) in the dark and under continuous (or occasionally shut) UV illumination, in (A) $1 \mathrm{M} \mathrm{HClO}_{4}$ and in (B) $0.5 \mathrm{M} \mathrm{MeOH}+1 \mathrm{M} \mathrm{HClO}_{4}$ solutions. (Arrows indicate potential scan direction; the photocurrent fall for the $\mathrm{TiO}_{2}-500$ electrode corresponds to a temporary illumination shut down.)

$\mathrm{Cu}$ electrodeposition on $\mathrm{TiO}_{2}$ /Ti electrodes: deposition voltammetry, microscopic (SEM) and spectroscopic (EDS) characterisation of $\mathrm{CU} / \mathrm{TiO}_{2}$ precursors

Figure 4 presents the cyclic voltammograms of the $\mathrm{TiO}_{2} / \mathrm{Ti}$ electrodes in a $\mathrm{Cu}^{++}$containing solution to obtain an exploratory electrodeposition picture. The cathodic electrodeposition peaks are observed for both types of electrodes (at potentials corresponding to the onset of the $\mathrm{Ti}(\mathrm{IV}) / \mathrm{Ti}(\mathrm{III})$ transformation shown in Figure 2) but interestingly no stripping peaks are recorded throughout the positive potential range. This means that the $\mathrm{Cu} / \mathrm{TiO}_{2}$ interface behaves as a Schottky diode with dark current (including that of electrodeposition) starting to flow only at 
potentials negative enough for $\mathrm{TiO}_{2}$ metallization and/or the onset of $\mathrm{Ti}$ surface reactions to occur. The fact that the onset of $\mathrm{Cu}$ electrodeposition should be related to the $\mathrm{Ti}(\mathrm{IV}) / \mathrm{Ti}(\mathrm{III})$ transformation (possibly via a catalytic cycle) is also supported by both phenomena exhibiting the same trend when one passes from an anatase-rich to a rutile-rich electrode.

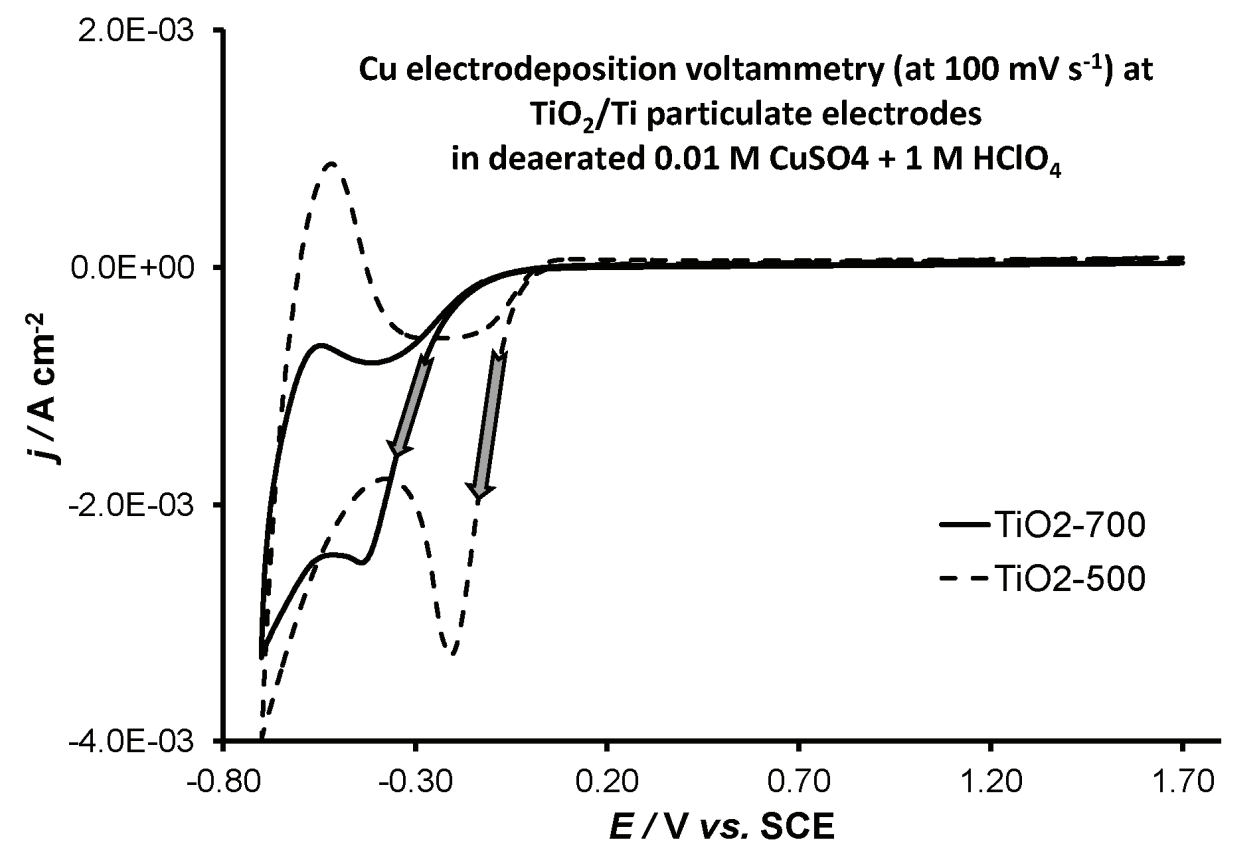

Figure 4. Cyclic voltammograms of $\mathrm{TiO}_{2} /$ Ti electrodes (anatase-rich/annealed at $500{ }^{\circ} \mathrm{C}$ for 1.5 $h$ and rutile-rich/annealed at $700{ }^{\circ} \mathrm{C}$ for $5 \mathrm{~h}$ ) in the dark, in the electrodeposition solution of $0.01 \mathrm{M} \mathrm{CuSO}_{4}+1 \mathrm{M} \mathrm{HClO}_{4}$ solution. (Arrows indicate potential scan direction.)

Constant potential $\mathrm{Cu}$ electrodeposition was carried out at the half-wave cathodic peak potential for each type of electrode and (in initial experiments) the electrodeposited Cu charge density was $400 \mathrm{mC} \mathrm{cm}$-2 for both electrodes. Figure 5 presents the SEM images (at different resolution) of such a $\mathrm{Cu} / \mathrm{TiO}_{2} / \mathrm{Ti}$ rutile-rich electrode. Numerous $\mathrm{Cu}$ particles of sub-micron dimensions can be seen to have been deposited onto/into the reticulated matrix of $\mathrm{TiO}_{2}$. A similar picture has been obtained for anatase-rich electrodes and, for typical $\mathrm{TiO}_{2}$-loadings of $2.2-2.4 \mathrm{mg} \mathrm{cm}^{-2}$ This procedure led to $\mathrm{Cu} / \mathrm{TiO}_{2}$ coating having a $17-18 \% \mathrm{w} / \mathrm{w} \mathrm{Cu}$ content (w.r.t. $\mathrm{TiO}_{2}$, as confirmed by EDS).
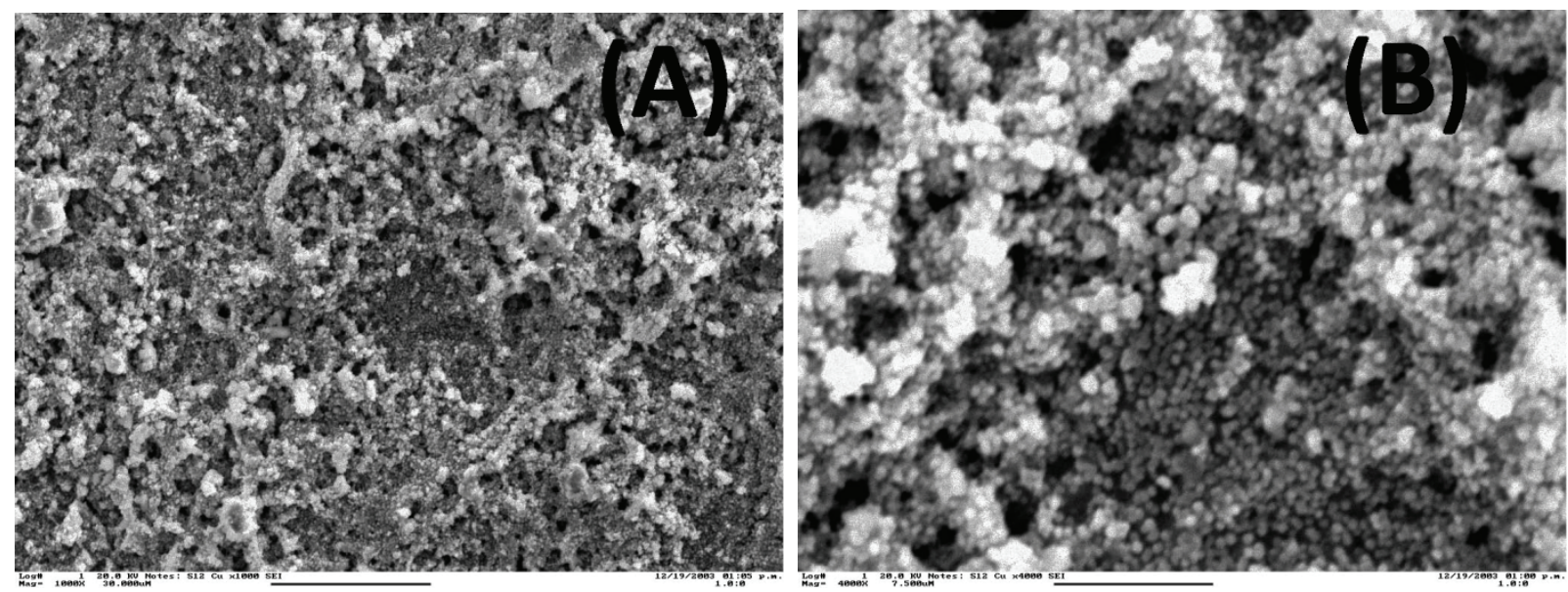

Figure 5. SEM micrographs of a CU/TiO 2 particulate film prepared by electrodeposition of $400 \mathrm{mC} \mathrm{cm}$ on a $\mathrm{TiO}_{2} / \mathrm{Ti}$ electrode (rutile-rich/ annealed at $700{ }^{\circ} \mathrm{C}$ for 5h). (Scale bar lengths: (A) $30 \mu \mathrm{m}$ and (B) $7.5 \mu \mathrm{m}$.) 
Galvanic replacement of $\mathrm{Cu}$ in $\mathrm{Cu} / \mathrm{TiO}_{2} / \mathrm{Ti}$ electrodes by Pt: microscopic, spectroscopic and electrochemical/photoelectrochemical characterization of $\mathrm{Pt}(\mathrm{Cu}) / \mathrm{TiO}_{2} / \mathrm{Ti}$ electrodes in acid

Upon immersion of the $\mathrm{Cu} / \mathrm{TiO}_{2}$ electrodes prepared as described in the previous section in a $10^{-3} \mathrm{M}$ chloroplatinate solution for $30 \mathrm{~min}, \mathrm{Cu}$ was replaced according to (2) by Pt. Figures 6 show SEM images of the thus produced $\mathrm{Pt}(\mathrm{Cu}) / \mathrm{TiO}_{2}$ coatings, revealing the existence of much smaller $\mathrm{Pt}$ nanoparticles (compared to those of the $\mathrm{Cu}$ precusrsor shown in Figures 5 ) and an increased porosity (intermediate of that of the $\mathrm{Cu} / \mathrm{TiO}_{2}$ precursor and of the $\mathrm{TiO}_{2}$ starting material), due to significant etching of $\mathrm{Cu}$ into the solution.

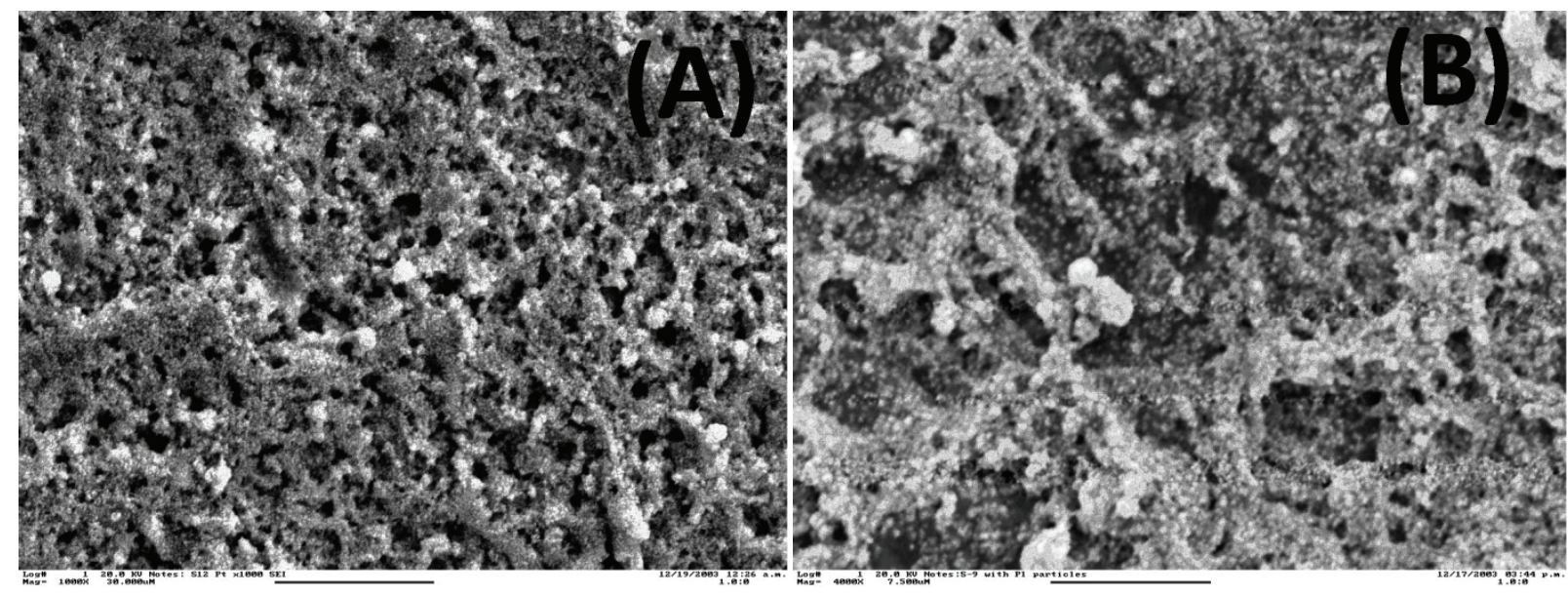

Figure 6. SEM micrographs of a Pt(Cu)/TiO 2 particulate film prepared from the $\mathrm{Cu} / \mathrm{TiO}$ film shown in Figure 4 above by immersion in a $10^{-3} \mathrm{M}$ chloroplatinic acid $+0.1 \mathrm{M} \mathrm{HCl}$ solution for $30 \mathrm{~min}$. (Scale bar lengths: (A) $30 \mu \mathrm{m}$ and (B) $7.5 \mu \mathrm{m}$.)

The EDS analysis of the $\mathrm{Pt}(\mathrm{Cu}) / \mathrm{TiO}_{2}$ deposits indicates that almost all $\mathrm{Cu}$ has been replaced or etched (only traces of $\mathrm{Cu}$ were measured) and that their Pt content is $6 \% \mathrm{w} / \mathrm{w}$ (w.r.t. $\mathrm{TiO}_{2}$ ) for rutile-rich electrodes and $2 \% \mathrm{w} / \mathrm{w}$ for anatase-rich electrodes. An insight into the mechanism of Pt deposition and the differences observed for the two substrates can be acquired by the following reasoning. The absence of significant quantities of $\mathrm{Cu}$ suggests that only $\mathrm{Pt}$ deposited directly onto $\mathrm{TiO}_{2}$ locations adjacent to $\mathrm{Cu}$ deposits survives (whereas Pt deposited on Cu locations collapses, as layers beneath it corrode from uncovered locations). Since it has already been reported that $\mathrm{Pt}$ nuclei are preferably formed on rutile (which has a larger concentration of oxygen vacancies) [43], it follows that larger quantities of Pt are deposited directly onto rutile-rich substrates than on anatase-rich ones. To be able to produce similar Pt loadings on both types of substrates, larger quantities of $\mathrm{Cu}$ had to be deposited on anatase-rich substrates. A 3-fold increase in pre-deposited $\mathrm{Cu}$ (plating density of $1200 \mathrm{mC} \mathrm{cm}^{-2}$ ) resulted in a $5 \% \mathrm{w} / \mathrm{w}$ Pt content. The rutile-rich and anataserich electrodes for which results are shown hereafter had Pt loadings of $0.15 \mathrm{mg} \mathrm{cm}$ and $0.12 \mathrm{mg} \mathrm{cm}^{-2}$, respectively.

Figures 7 present the surface electrochemistry of the $\mathrm{Pt}(\mathrm{Cu}) / \mathrm{TiO}_{2} / \mathrm{Ti}$ electrodes in deaerated acid. 

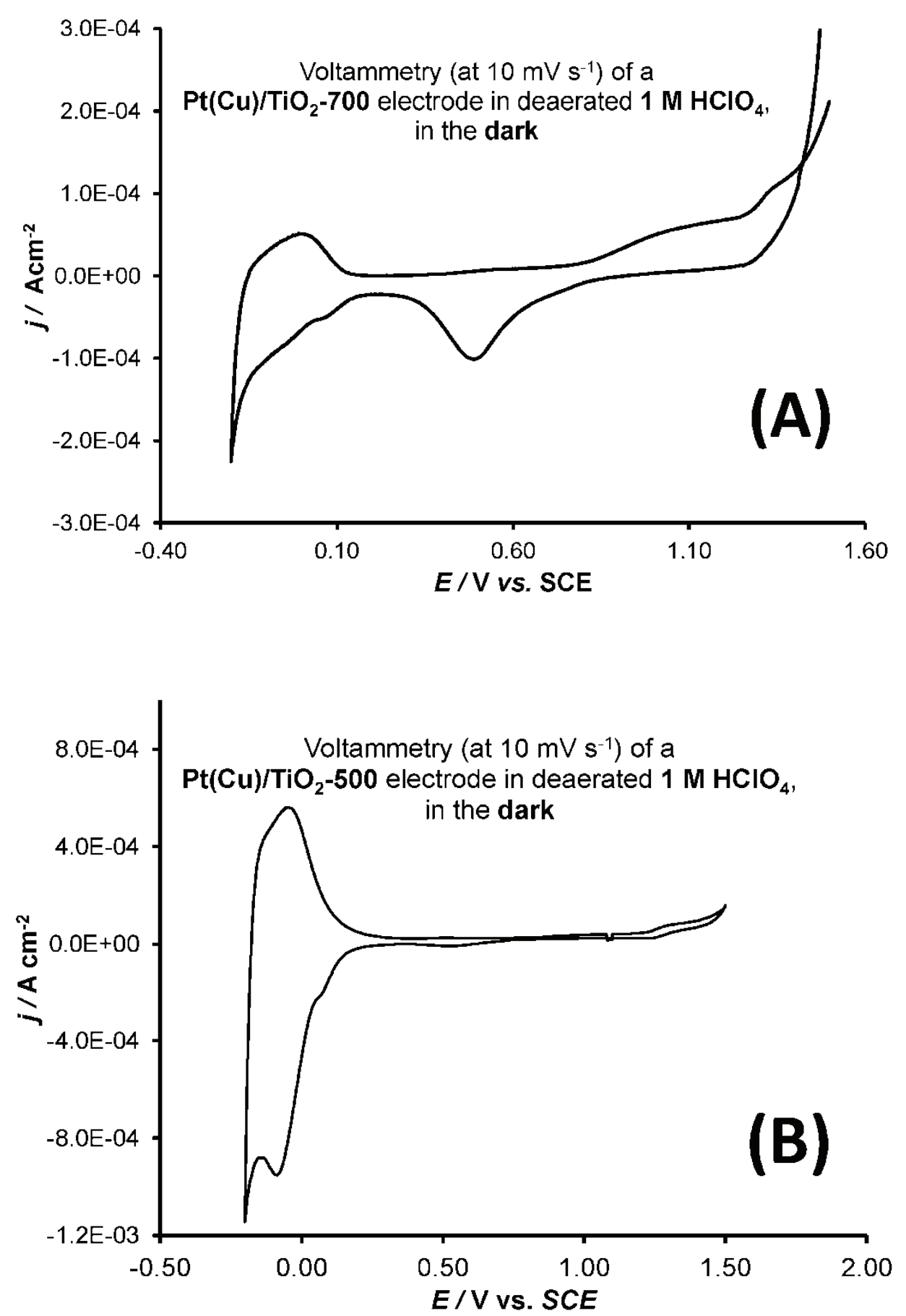

Figure 7. Cyclic voltammograms of $\mathrm{Pt}(\mathrm{Cu}) / \mathrm{TiO}_{2} / \mathrm{Ti}$ electrodes in the dark, in a deaerated $1 \mathrm{M} \mathrm{HClO}_{4}$ solution. (A) Rutile-rich electrode/annealed at $700{ }^{\circ} \mathrm{C}$ for $5 \mathrm{~h}$;

(B) Anatase-rich electrode/annealed at $500^{\circ} \mathrm{C}$ for $1.5 \mathrm{~h}$.

Although the rutile-rich electrode shows the typical polycrystalline Pt picture (with the hydrogen adsorption/desorption and oxide formation/stripping peaks), there are only traces of oxide formation and stripping for the anatase-rich electrode. In this case, the formation of a Schottky diode between the metal $(\mathrm{Pt})$ and the n-type semiconductor $\left(\mathrm{TiO}_{2}\right)$ which would allow for currents at potentials negative to the flat band potential and cut them off at more positive potentials, is not a plausible scenario. This is because, as shown in Figures 8 , hydrogen evolution occurs at $\mathrm{Pt}(\mathrm{Cu}) / \mathrm{TiO}_{2}$ at potentials far more positive than the $\mathrm{TiO}_{2}$ metallization region; 
furthermore some anodic reactions (ferrocyanide oxidation and hydrazine-not shown here) did take place on the anatase-rich electrodes in the potential range of Pt oxide formation and stripping.
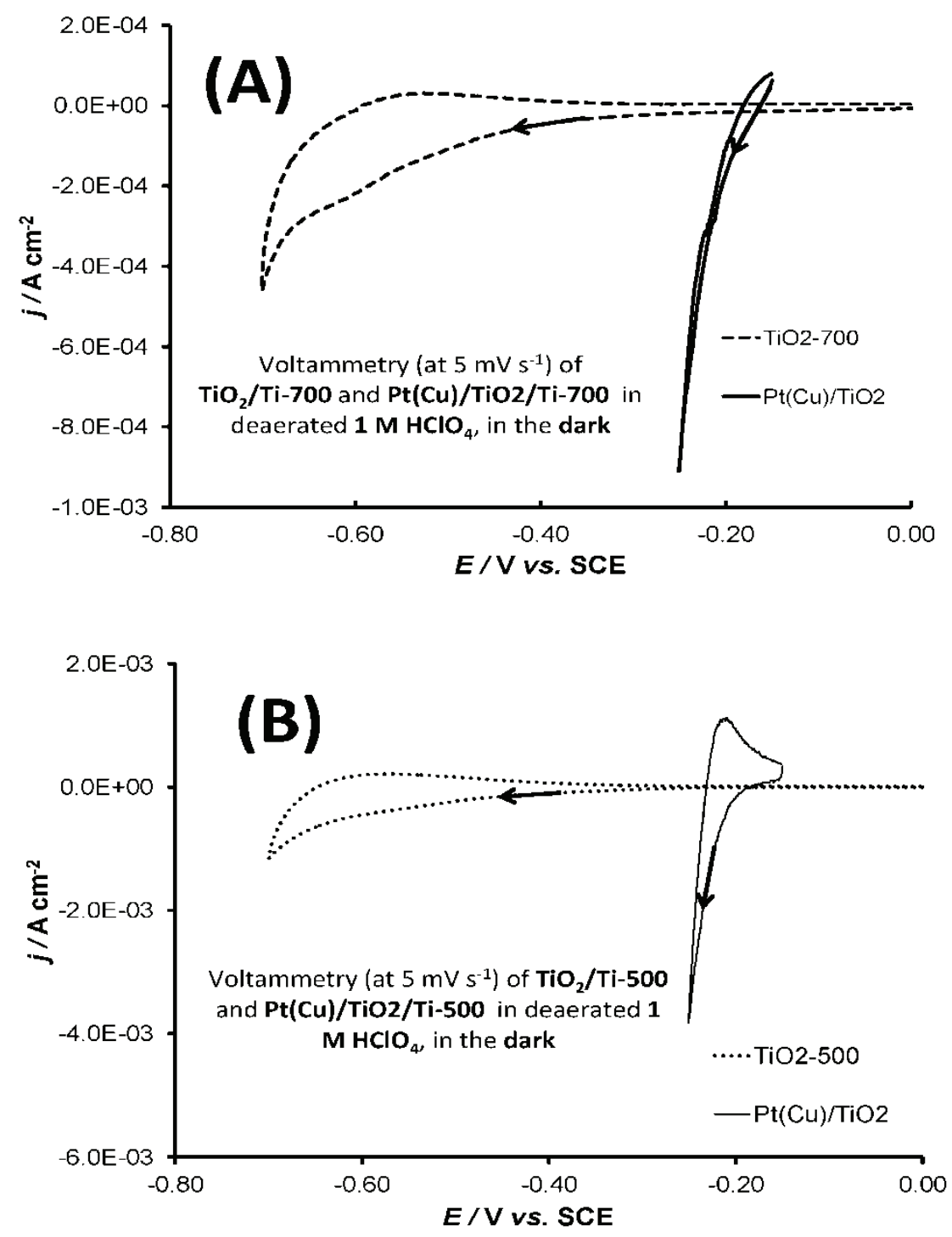

Figure 8. Slow potential scan voltammograms of $\mathrm{Pt}(\mathrm{Cu}) / \mathrm{TiO}_{2} / \mathrm{Ti}$ and $\mathrm{TiO}_{2} / \mathrm{Ti}$ electrodes in the dark, in a deaerated $1 \mathrm{M} \mathrm{HClO}_{4}$ solution. (A) Rutile-rich electrode/annealed at $700{ }^{\circ} \mathrm{C}$ for $5 \mathrm{~h}$;

(B) Anatase-rich electrode/annealed at $500{ }^{\circ} \mathrm{C}$ for $1.5 \mathrm{~h}$.

All this means that electron transfer reactions are possible at the Pt overlayer via resonance tunneling from $\mathrm{Pt}$ to the $\mathrm{Ti}$ base of the electrode through the $\mathrm{TiO}_{2}$ semiconductor, with the help of an impurity band introduced by Pt [44]. Therefore, the supression of Pt oxide/formation is to be attributed to strong Pt-anatase interactions. It should be noted that the extraordinary picture of Figure $7(B)$ has also been reported for platinized reduced anatase [45], monocrystalline rutile [46] or low Pt coverage/small particle size anatase-rich samples [47], and can been interpreted via the formation of a strong Pt-Ti bond [48], inhibiting the formation of PtO. The reason why these interactions are higher for anatase substrates is due to the fact that smaller nuclei (thus more affected by the $\mathrm{TiO}_{2}$ in contact) and stronger Pt adsorption are observed at anatase [43] (despite the formation of larger Pt clusters at rutile locations). From the charge under the cathodic hydrogen adsorption peak the Pt electroactive area per electrode substrate geometric area 
(roughness factor) can be calculated as 10 for rutile-rich and 81 for anatase-rich electrodes, close or within the lower part of the 50-1000 range of Pt black or carbon-supported Pt fuel cell catalysts [17]. Taking into account the loading of each electrode, these values of the roughness factor are translated to ca 6.5 and $67.5 \mathrm{~m}^{2} \mathrm{~g}^{-1}$ of electroactive Pt (note that a typical fuel cell catalyst has a value of $65 \mathrm{~m}^{2} \mathrm{~g}^{-1}$ [49]). The higher surface area/dispersion of $\mathrm{Pt}$ in anatase-rich electrodes is in line with the above-mentioned reasoning for stronger $\mathrm{Pt}^{-\mathrm{TiO}_{2}}$ interactions at these substrates.

Figures 9 (A)-(B) show the effect of UV illumination on the cyclic voltammetry of the $\mathrm{Pt}(\mathrm{Cu}) / \mathrm{TiO}_{2} / \mathrm{Ti}$ electrodes in acid. A comparison with the results of the corresponding $\mathrm{TiO}_{2} / \mathrm{Ti}$ electrodes of Figure $3(A)$, reveals that there is approximately a 3 -fold decrease of the net photocurrent at both electrodes (from 116 to $40 \mu \mathrm{A} \mathrm{cm} \mathrm{cm}^{-2}$ for the rutile-rich electrode and from 61 to $22 \mu \mathrm{A} \mathrm{cm}^{-2}$ for the anatase-rich electrode, at $\left.+0.80 \mathrm{~V}\right)$.
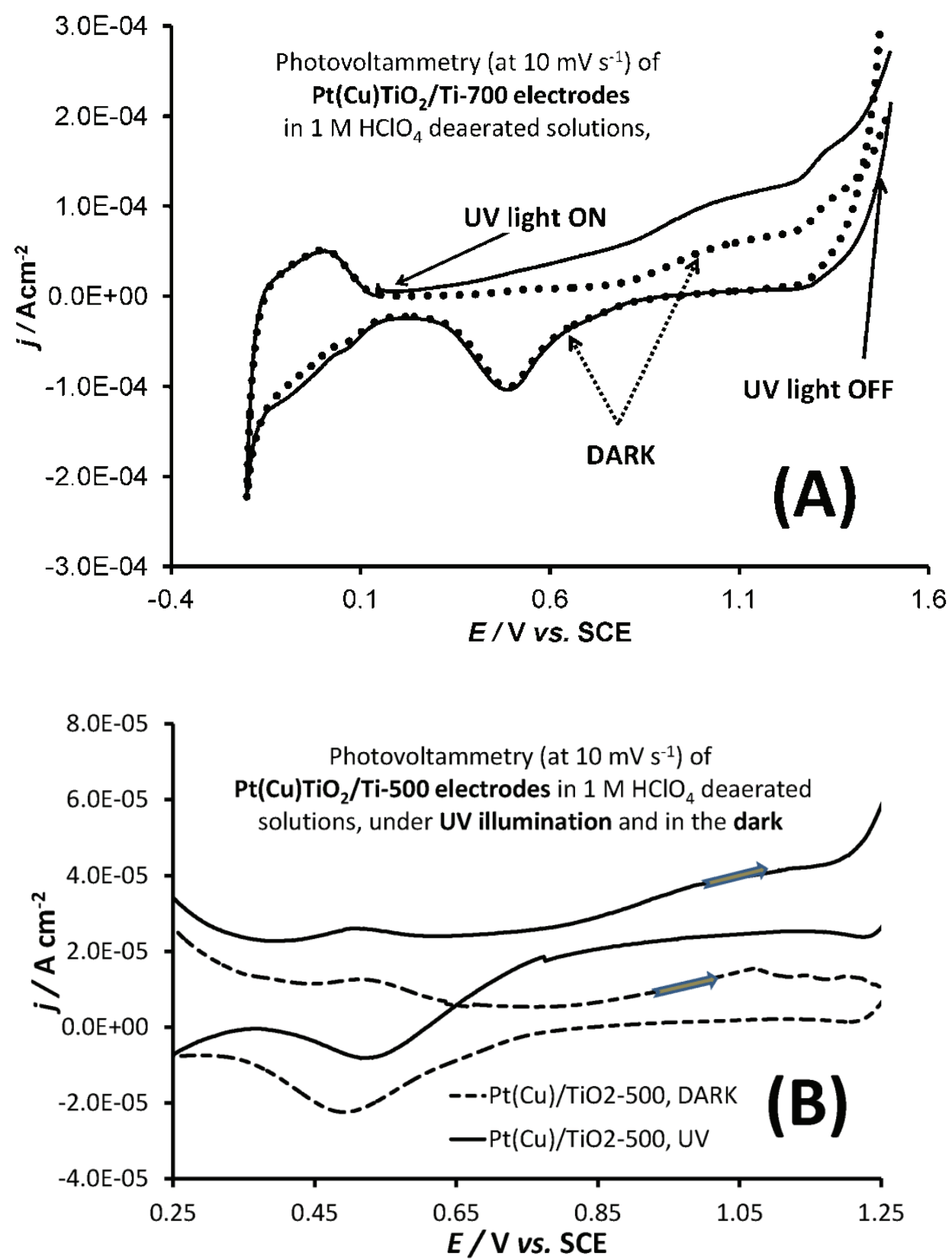

Figure 9. Cyclic voltammograms of $\mathrm{TiO}_{2} /$ Ti electrodes in the dark and under UV illumination, in $1 \mathrm{M} \mathrm{HClO}_{4}$. (A) Rutile-rich electrode/annealed at $700{ }^{\circ} \mathrm{C}$ for $5 \mathrm{~h}$; (B) Anatase-rich electrode/annealed at $500{ }^{\circ} \mathrm{C}$ for $1.5 \mathrm{~h}$. 
This is opposite to the beneficial effect that Pt has on plain photocatalysis but it is to be expected since first, Pt loading of the photoelectrocatalysts prepared in this work $(8-10 \% \mathrm{w} / \mathrm{w})$ is much higher than that of Pt-doped $\mathrm{TiO}_{2}$ photocatalysts $(0.1-1 \% \mathrm{w} / \mathrm{w})$ resulting to partial shielding of $\mathrm{TiO}_{2}$ from light and second, the addition of a metal should not have a key role in decreasing charge recombination during photoelectrocatalysis since this is mainly achieved by the electrical bias.

\section{Methanol oxidation at Pt(Cu)/TiO $/$ /Ti electrodes in the dark and under UV illumination}

Figure 10 presents slow potential sweep cyclic voltammograms (at $10 \mathrm{mV} \mathrm{s}^{-1}$; third cycle) of the $\mathrm{Pt}(\mathrm{Cu}) / \mathrm{TiO}_{2} / \mathrm{Ti}$ electrodes, in a $0.5 \mathrm{M} \mathrm{MeOH}+0.1 \mathrm{M} \mathrm{HClO}_{4}$ solution. Although the typical voltammetric picture for methanol oxidation on $\mathrm{Pt}$ is observed (an oxidation peak showing distinct hysterisis), the current densities are rather low and the anatase-rich electrode is almost ten times inferior to the rutile-rich electrode. The latter trend can be interpreted by the absence of significant Pt oxide formation at the anatase-rich electrode (see Figure $7(B)$ ) and the crucial role of these oxides in oxidizing/removing the carbonaceous intermediates/poisons of methanol oxidation. Note that a similar correlation has been found for methanol oxidation at $\mathrm{Pt} / \mathrm{TiO}_{2}$ electrodes in [47].

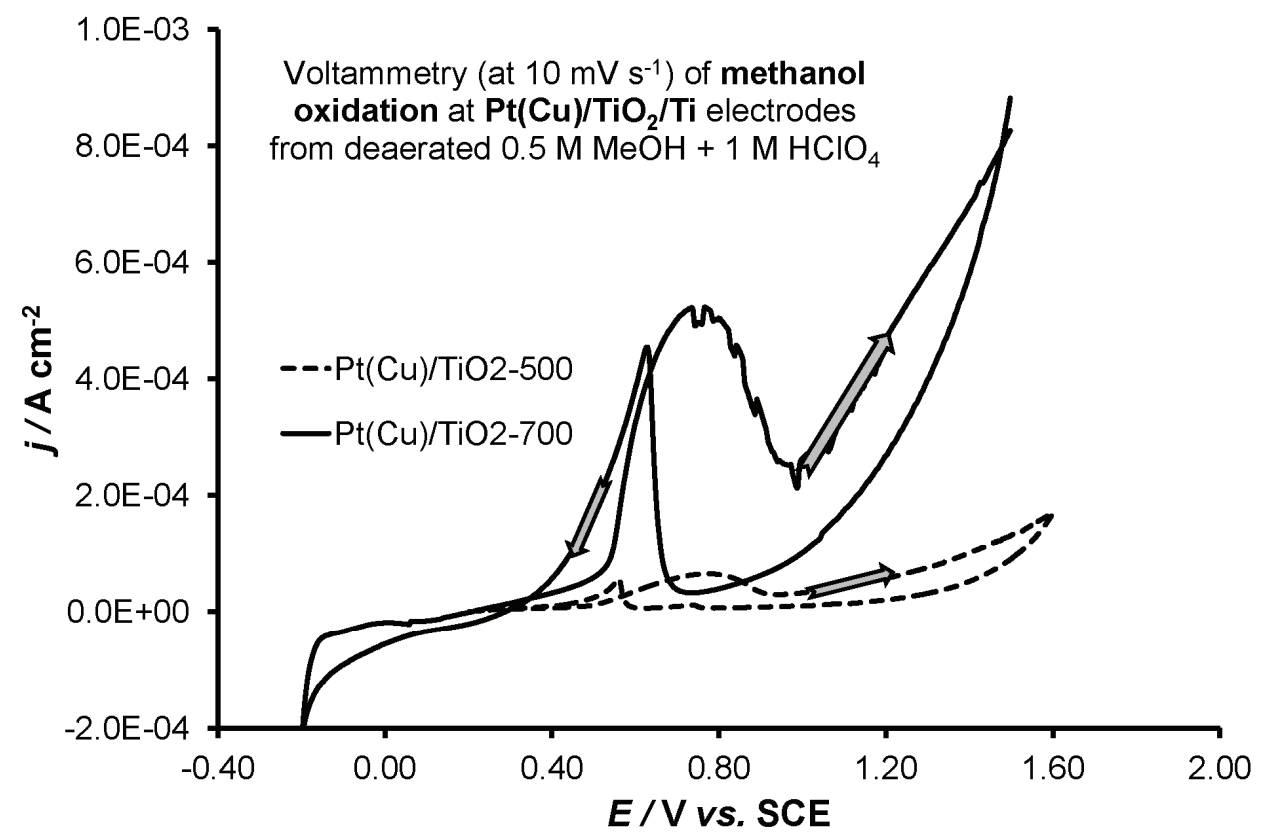

Figure 10. Cyclic voltammograms of $\mathrm{Pt}(\mathrm{Cu}) / \mathrm{TiO}_{2} / \mathrm{Ti}$ electrodes (anatase-rich/annealed at $500^{\circ} \mathrm{C}$ for $1.5 \mathrm{~h}$ and rutile-rich/annealed at $700{ }^{\circ} \mathrm{C}$ for $5 \mathrm{~h}$ ) in the dark, in a $0.5 \mathrm{M} \mathrm{MeOH}+0.1 \mathrm{M} \mathrm{HClO}_{4}$ solution. (Arrows indicate potential scan direction.)

The Pt mass-specific current density of the rutile-rich $\mathrm{Pt}(\mathrm{Cu}) / \mathrm{TiO}_{2}$ catalyst can be estimated as 3.6 $\mathrm{mA} \mathrm{mg}^{-1}$ (at the peak potential) which is lower than commonly observed values at $\mathrm{Pt} / \mathrm{C}$ catalysts (see for example the value of ca $15 \mathrm{~mA} \mathrm{mg}^{-1}$ of a commercial Pt/C(E-Tek) catalyst under same methanol concentration and similar scan rate conditions [50]). This is to be expected for the rutile-rich electrode which (based on Pt surface electrochemistry) was found to have a small Pt electroactive surface area (see discussion above). However, when compared to the performance of the $\mathrm{Pt} / \mathrm{TiO}_{2}$ catalyst prepared by photodeposition in [17] and resulting in a massive $10 \mathrm{mg} \mathrm{cm}^{-2}$ $\mathrm{Pt}$ loading and/or losses (depending on the amounts deposited onto the substrate or the reactor 
walls), our catalyst (with a $0.15 \mathrm{mg} \mathrm{cm}^{-2} \mathrm{Pt}$ loading) is superior. This is because the photodeposited catalyst of [17] gives methanol oxidation currents in the 1.5-3 $\mathrm{mA} \mathrm{mg}^{-1}$ range (after correction for different concentrations and depending on scan rate).

Figure 11 shows the effect of UV illumination on methanol oxidation at the rutile-rich electrode. The enhancement factor of the peak current is calculated as 1.66 and the net increase is some $344 \mu \mathrm{A} \mathrm{cm}$. The latter is much higher than the net photocurrent of $40 \mu \mathrm{A} \mathrm{cm}$ recorded at the same $\mathrm{Pt}(\mathrm{Cu}) / \mathrm{TiO}_{2} / \mathrm{Ti}$ electrode in the acid supporting electrolyte (Figure $9(\mathrm{~A})$ ) and even higher than the limiting photocurrent of $260 \mu \mathrm{A} \mathrm{cm}$ observed on the plain $\mathrm{TiO}_{2} / \mathrm{Ti}$ electrode in the presence of methanol (Figure $3(\mathrm{~B})$ ). This in turn indicates that the oxidation current enhancement observed at the $\mathrm{Pt}(\mathrm{Cu}) / \mathrm{TiO}_{2} / \mathrm{Ti}$ electrode upon illumination in the presence of methanol is not merely due to the superposition of methanol oxidation on $\mathrm{Pt}$ and photooxidation on $\mathrm{TiO}_{2}$ but due to a synergistic effect, most likely the photooxidative removal of poisonous intermediates from $\mathrm{Pt}$ sites at neighbouring $\mathrm{TiO}_{2}$ sites.

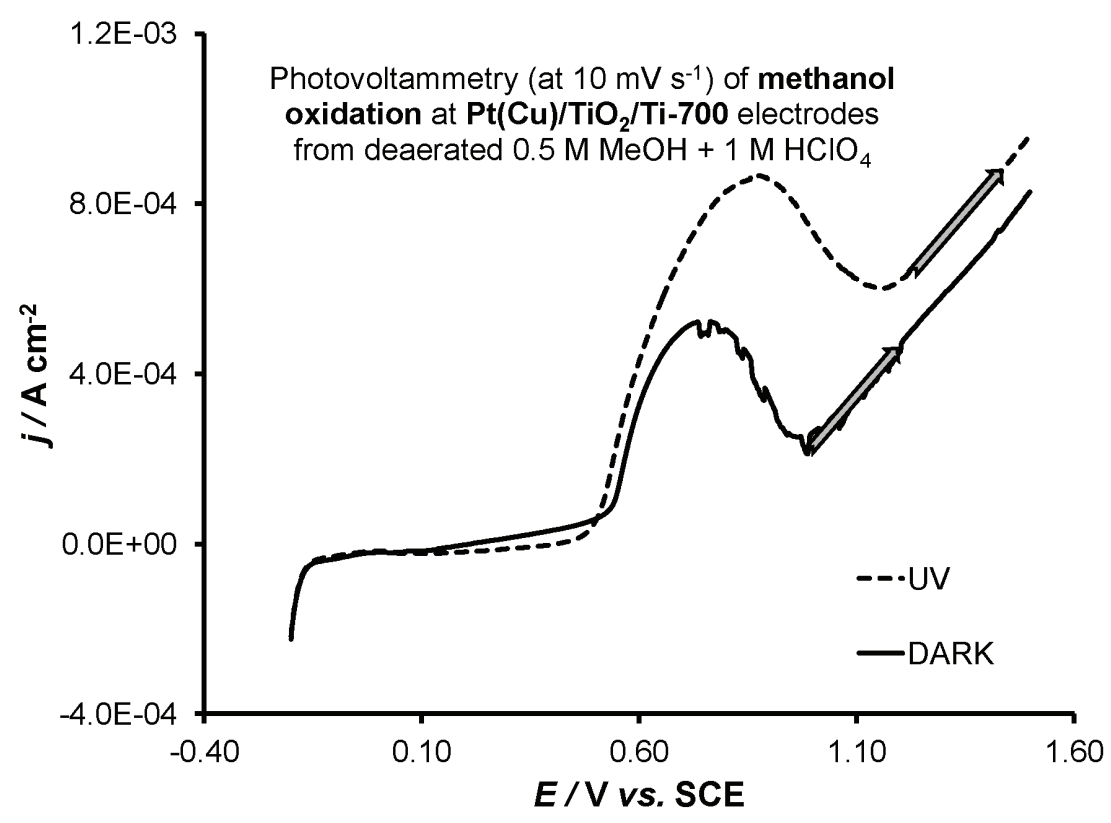

Figure 11. Voltammograms of a Pt $(\mathrm{Cu}) / \mathrm{TiO}_{2} / \mathrm{Ti}$ electrode (rutile-rich/annealed at $700^{\circ} \mathrm{C}$ for $5 \mathrm{~h}$ ) in the dark and under UV illumination, in a $0.5 \mathrm{M} \mathrm{MeOH}+1 \mathrm{M} \mathrm{HClO}_{4}$ solution. (Arrows indicate potential scan direction.)

\section{Conclusions}

i. It has been demonstrated that the two-step electrodeposition-galvanic replacement technique (previously applied to metallic substrates) can be successfully applied to semiconductor oxides too. Hence, following $\mathrm{Cu}$ electrodeposition on particulate $\mathrm{TiO}_{2}$ electrode coatings and its subsequent replacement by $\mathrm{Pt}$, stable $\mathrm{Pt}(\mathrm{Cu}) / \mathrm{TiO}_{2}$ catalytic layers can be formed.

ii. Depending on whether the $\mathrm{TiO}_{2}$ substrate was rutile-rich or anatase-rich, the formation and stripping of Pt surface oxides could or could not be seen in cyclic voltammetry experiments. This indicates stronger interactions between $\mathrm{Pt}$ and anatase than between $\mathrm{Pt}$ and rutile.

iii. As a direct consequence of the above point, methanol oxidation in the dark is largely suppressed at platinized anatase-rich electrodes. (Since the suppression of Pt oxide formation is known to have a beneficial effect on oxygen reduction, such electrodes are worth testing in that reaction.) 
iv. The significant methanol oxidation current enhancement observed upon the UV illumination of the platinized rutile-rich electrodes (due to $\mathrm{Pt}$ and $\mathrm{TiO}_{2}$ synergism) makes more research into their optimisation worth pursuing.

Acknowledgements: This research has been co-financed by the European Union (European Social Fund - ESF) and Greek national funds through the Operational Program "Education and Lifelong Learning" of the National Strategic Reference Framework (NSRF) - Research Funding Program: Heracleitus II. Investing in knowledge society through the European Social Fund.

\section{References}

[1] S.Trasatti (Ed.), Electrodes of Conductive Metallic Oxides Parts A and B, Elsevier, Amsterdam , 1980-1981

[2] A.C.C.Tseung,, S.Yeh, X.Liu, G.H.Kelsall and P.Dykstra, Novel Acid Resistant Oxygen Evolution Anodes, Commission of the European Communities, Brussels, (1990) p.9

[3] Ulman's Encyclopedia of Industrial Electrochemistry, vol. A6, VCH, Weinheim(1986)

[4] H.I.Warren, Anodes for Electrowinning, D.J.Robinson (Ed.), The Metallurgical Society of AIME, (1984) p.79

[5] V. Subramanian, E. Wolf, P.V. Kamat, J. Phys. Chem. B 105 (2001) 11439-11446

[6] T. Ohsawa, Y. Yamamoto, M. Sumiya, Y. Matsumoto, H. Koinuma, Langmuir 20(2004) 3018

[7] B. Wen, C. Liu, Y. Liu, J. Phys. Chem. B 109 (2005) 12372-12375

[8] J.-M. Lee, S.-B. Han, J.-Y. Kim, Y.-W. Lee, A.-R. Ko, B. Roh, I. Hwang, K.-W. Park, Carbon 48(8) (2010) 2290-2296

[9] H. Song, P. Xiao, X. Qiu, W. Zhu, J. Power Sources 195(6) (2010) 1610-1614

[10] G. Selvarani, S. Maheswari, P. Sridhar, S. Pitchumani, A.K. Shukla, J. Electrochem. Soc. 156(11) (2009) B1354-B1360

[11] C.S. Chen, F.-M. Pan, Appl. Catal. B-Environ. 91(3-4) (2009) 663-669

[12] E. Mahe, D. Devilliers, Electrochim. Acta 46 (2001) 629-636

[13] J.V. Macpherson, J.-P. Gueneau de Mussy, Electrochem. Solid State Let. 4(9) (2001) E33-E36

[14] J.V. Macpherson, J.-P. Gueneau de Mussy, J. Electrochem. Soc. 149(7) (2002) B306-313

[15] G.A. Hope, A.J. Bard, J. Phys .Chem. 87 (1983) 1979-1984

[16] K. Tammeveski, T. Tenno, A. Rosental, P. Talonen, L.-S. Johansson, L. Niinisto, J. Electrochem. Soc. 146(2) (1999) 669-676

[17] B.E. Hayden, D.V. Malevich, D. Pletcher, Electrochem. Commun. 3 (2001) 395-399

[18] X.-Z. Li, F.-B. Li, J. Appl. Electrochem. 32 (2002) 203-210

[19] L. Xiong, A. Manthiram, Electrochim. Acta 49 (2004) 4163-4170

[20] S.R. Branković, J.X. Wang, R.R. Adžić, Surf. Sci. 474 (2001) L173-L179

[21] S.R. Branković, J. McBreen, R.R. Adžić, J. Electroanal. Chem. 503 (2001) 99-104

[22] S.R. Branković, J. McBreen, R.R. Adžić, Surf. Sci. 479 (2001) L363-368

[23] M. Van Brussel, G. Kokkinidis, I. Vandendael, C. Buess-Herman, Electrochem. Commun. 4(10) (2002) 808-813

[24] M. Van Brussel, G. Kokkinidis, A. Hubin, Cl. Buess-Herman, Electrochim. Acta 48 (2003) 3909-3919

[25] S. Papadimitriou, A. Tegou, E. Pavlidou, G. Kokkinidis, S. Sotiropoulos, Electrochim. Acta 52 (2007) 6254-6260

[26] A. Tegou, S. Papadimitriou, E. Pavlidou, G. Kokkinidis, S. Sotiropoulos, J .Electroanal. Chem. 608 (2007) 67-77

[27] S. Papadimitriou, A. Tegou, E. Pavlidou, G. Kokkinidis, S. Sotiropoulos, Electrochim. Acta 53 (2008) 6559-6567 
[28] A. Tegou, S. Papadimitriou, S. Armyanov, E. Valova, G. Kokkinidis, S. Sotiropoulos, J. Electroanal. Chem. 623(2) (2008) 187-196

[29] A. Tegou, S. Papadimitriou, G. Kokkinidis, S. Sotiropoulos, J. Solid State Electrochem. 14(2) (2010) 175-184

[30] S. Papadimitriou, S. Armyanov, E. Valova, A. Hubin, O. Steenhaut, E. Pavlidou, G. Kokkinidis, S. Sotiropoulos, J. Phys. Chem. C 114(11) (2010) 5217-5223

[31] Y. Ando, K. Sakaki, R. Adzic, Electrochem. Commun. 11 (2009) 1135-1138

[32] B.I. Podlovchenko, T.D. Gladysheva, A.Yu. Filatov, L.V. Yashina, Russ. J. Electrochem. 46(10) (2010) 1189-1197

[33] K.-W. Park, S.-B. Han, J.-M. Lee Electrochem. Commun. 9 (2007) 1578-1581

[34] S. Bakardjieva, J. Subrt, V. Stengl, M.J. Dianez. J. Sayagues, Appl. Catal. B-Environ. 58 (2005) 193-202

[35] V.B. Baez, J.E. Graves, D. Pletcher, J. Electroanal. Chem. 340 (1992) 273-286

[36] V.B. Baez and D. Pletcher, J. Electroanal. Chem. 377 (1994) 231-240

[37] V.B.Baez and D.Pletcher, J. Electroanal. Chem. 382 (1995) 59-64

[38] D.N. Furlong, D.E. Yates, T.W. Healy, in S. Trasatti (Ed.), Electrodes of Conductive Metallic Oxides, Elsevier, Amsterdam, 1981, p.375

[39] B. O'Regan, J. Moser, M. Gratzel, J. Phys. Chem. 94 (1990) 8720-8726

[40] K. Vinodgopal, S. Hotchandani, P.V. Kamat, J. Phys. Chem. 97 (1993) 9040-9044

[41] S. Sodergren, A. Hagfeldt, J. Olsson, S.-E. Lindquist, J. Phys. Chem. 98 (1994) 5552-5556

[42] J. Augustynski, in A.Wieckowski (Ed.), Interfacial Electrochemistry: Theory, Experiment and Applications, Marcel Dekker Inc., NY, 1999, p.707

[43] H.Iddir, V. Skavysh, S. Agut, N.D. Browning, M.M. Disko, Physical Review B - Condensed Matter and Materials Physics, 73(4) (2006) art. no. 041403

[44] L. Avalle, E. Santos, V.A. Macagno, Electrochim. Acta 39 (1994) 1291-1295

[45] J. Sanchez, M. Koudelka, J. Augustynski, J. Electroanal. Chem. 140 (1982) 161-166

[46] K. Uosaki, R. Yoneda, H. Kita, J. Phys. Chem. 89 (1985) 4042-4046

[47] B.E. Hayden, D. Pletcher, J.-P. Suchsland, L.J. Williams Phys. Chem. Chem. Phys. 11 (2009) 1564-1570

[48] J.A. Horsley, J. Am. Chem. Soc. 101(11) (1979) 2870-2874

[49] M. Hampden-Smith, P. Atanassova, P. Atanassov, T. Kodas, in W. Vieltich, A. Lamm, H.A. Gasteiger (Eds.), Handbook of Fuel Cells: Fundamentals Technology and Applications, Vol.3, Wiley, Chichester, England, 2003, p.506

[50] M. Chen, Z.-B. Wang, Y. Ding, G.-P. Yin, Electrochem. Commun. 10 (2008) 443-446

(C) 2012 by the authors; licensee IAPC, Zagreb, Croatia. This article is an open-access article distributed under the terms and conditions of the Creative Commons Attribution license (http://creativecommons.org/licenses/by/3.0/) (cc) Er 